\title{
Identification of common milk adulterants using in Mirzapur city
}

\author{
Pooja Jaiswal ${ }^{1}$ and S. K. Goyal ${ }^{2}$ \\ ${ }^{1}$ Student of PGDFSQM, IGNOU, BHU (Study Center Code - 48003P), Varanasi (U.P.) \\ ${ }^{2}$ Assistant Professor, KVK, Instt. of Agril. Sciences, Mirzapur (U.P.)
}

\begin{abstract}
Two types of the milk samples i.e. 30 raw and 20 packaged (total 50) were collected from 10 different cites (Dankeen Ganj, Panditan, Railway Bazar, Bus Station, Bharhuna, Vindhyachal, Peelikothi, Awas Vikas Colony, Wellesly Ganj and Mahuria) of the Mirzapur city. Adulteration tests were conducted for urea, salt, soap, skimmed milk power, glucose, formalin, salicylic acid, boric acid, starch and ammonium sulphate. $80 \%, 56 \%$ and $54 \%$ samples tested were found positive for urea, salt and soap, respectively. While, $42 \%$ milk samples were found positive for skimmed milk powder test. Only $10 \%$ samples were positive for glucose. Similarly, 36\% of milk samples were found positive for formalin. The extent of adulteration of salicylic acid, boric acid, starch and ammonium sulphate is depicted that $56 \%$ and $32 \%$ number of milk were noticed positive for salicylic acid and boric acid. It is also evident from the findings that $38 \%$ samples were adulterated with starch. While, $12 \%$ of collected samples (raw and packaged) were observed positive for ammonium sulphate.
\end{abstract}

Keywords: Adulterants, raw milk, packaged milk, Mirzapur

Paper cited: Jaiswal, P. and Goyal, SK. (2016). Identification of common milk adulterants using in mirzapur. South Asian Journal of Food Technology and Environment, 2(1): 313-320

Received: 02/03/2016 Revised: 13.03.2016 Accepted: 17/03/2016

\section{Introduction}

It is not exactly known when man started utilizing milk of other animals for his benefit, but the importance of milk in our diet has been recognized since Vedic Times. India is ranked first in production of milk in the world followed by United States, China, and Germany. Production of milk of India was around 146.3 million tonnes in 2014-15 and per capita availability $322 \mathrm{~g}$ per day according to NDDB (NDDB, 2016). Country has almost reached $17 \%$ of World milk production. Milk has been recognized as an almost complete food for man as it is a source of essential nutrients like carbohydrates, protein, fat, vitamins and minerals. Milk is required for promoting growth and maintenance of health. It can however also serve as a vehicle for transmission of chemicals and other impurities. Milk plays an important role in building a healthy society and can be used as vehicle for rural development, employment and slowing down the migration of the rural population (Sarwar et al., 2002).

India is the largest producer and consumer of milk and milk products in the world. With rapid economic growth, the demand for milk is expected to increase at a faster pace than supply and the resulting supply-demand gap could reach 50 million tons by 2030 (Mahmood and Usman, 2010). Billions of people around the world consume milk and dairy products every day. Milk and dairy products are vital source of nutrition for these people, they also present livelihoods opportunities for farmers, processors, shopkeepers and other stakeholders in the dairy value chain (Grace et al., 2009). But to achieve this, consumers, industry and governments need up-to-date information on how milk and dairy products can contribute to human nutrition?

\section{Justification of the present study}

Historically, the uses of adulterants has been common in societies form ancient time with few legal controls on food quality due to poor of nonexistent monitoring by authorities; sometimes this usage has even extended to exceedingly dangerous chemicals and poisons. The safety of milk and dairy products must be ensured to protect vulnerable 
consumers such as children for whom milk can be a beneficial dietary component. Raw or poorly processed and/or handled milk and milk products can lead to food-borne illness in humans. A great deal is known about the sources of hazards that can compromise the safety of milk and dairy products, the necessary controls and preventive measures to ensure products are safe. The risk-reduction measures required vary with the hazard and the intrinsic product characteristics so that while it may not always be necessary to eliminate the hazard completely, its presence must be minimized to provide an acceptable and safe level of consumer protection. Raw milk or raw-milk products should be individually assessed for their potential risk to public health and appropriate riskmanagement strategies implemented. Such type of study has not been conducted to assess the quality of milk supplied in Mirzapur city of Eastern U.P. Hence, there was an urgent need to conduct the present investigation for safe life of population residing in this area.

Milk is transported from the point of production to consumers and processing plants by middlemen called "Gawalas". They don't maintain proper hygienic conditions during transport, which leads to increase the total viable bacterial count. They also adulterate milk to increase their profit margin by several chemicals like urea, starch, flour, cane sugar, vegetable oils, detergents etc. Various preservatives like formalin and some antibiotics are also added in milk to increase its shelf life. This addition decreases the nutritive value of milk. These adulterants, preservatives and drugs in milk cause very serious health related problems (Lingathuri et al., 2009).

It is difficult to get a food item, may be flour, pulse, oil, fruit, vegetable, milk, sweet, spices, tea, coffee, honey, bakery item, chocolate, beetal nut including fruit juice which is free from one or the other adulterants. Our lunch or dinner thali (containing dal, roti, rice, vegetable and salad) is also not safe. Even animal feed like cake as protein supplement for lactating animals is adulterated. 90 per cent of un-branded loose items are adulterated. Food contamination occurs from different sources, viz. overuse and illegal use of pesticides in agriculture, industrial sludge if not treated before use, air pollution and use of pesticides for storing. Ever input from water to manure and from pesticides to preservatives contributes to contamination. Incidences of adulteration in milk and milk products are at increase over the years. Milk is adulterated at two stages: production and postproduction (ditribution). Use of hormones, viz. growth hormone to boost milk production and oxytocin for milk letdown is rampant. Both the hormones have adverse effects on animal and human health (Alauddin, 2012).

Oxytocin affects fertility of animals whereas consumption of oxytocin induced milk may cause cancer and heart problems. High pesticides content in the food and water makes even mother's breast milk unsafe. Mother's milk in India has the highest DDT levels in the world. Milk form animals suffering from mastitis highly infectious and can lead to asthma, allergy and diarrhea. Normally, milk form such animals should be discarded. Dairymen rather than discarding such milk, mix with other milk and supply to consumers. Ammonium compounds, $\mathrm{NaOH}$, $\mathrm{Na}_{2} \mathrm{CO}_{3}$, hydrogen peroxide, formalin, sodium sulphate and poster paints are common adulterants in milk for increasing the self life (Kandpal et al., 2012).

According to a report from World Bank supported National Agricultural Technology Project (NATP), 27 per cent milk samples collected from Uttar Pradesh, Haryana, Delhi, Punjab and Rajasthan were found to be adulterated with one or more adulterant(s). Water is the common adulterant to increase the volume of milk. Adulteration of loose milk with water is very simple. Even poly packed milk is not safe from such adulteration. The ingredients used in the manufacture of synthetic milk are caustic soda, very low quality refined oil, common salt, sugar, urea, detergent powder and water. Some time even stale milk powder also used. All the ingredients used for production of synthetic milk are harmful. Consequent use damages the intestines, makes them prone to diseases such as gastroenteritis, diarrhea and malnutrition. Children are more prone for such damages. The practice of synthetic milk preparation is widespread and more prevalent in Western Uttar Pradesh, Haryana and Himachal Pradesh. The source of adulteration of milk products is twofold: (1) use of adulterated milk and (2) 
adulteration during product preparation. Adulteration of skimmed milk powder with chalk powder is prevalent in many parts of the country (NDRI, 2002). Antibiotics are added to milk and milk products to increase the self life. Consumption of milk and milk products adulterated with antibiotics can build up antibiotic resistant organism in the body (Wadekar et al., 2011).

Nirwal et al. (2013) analyzed the milk for adulteration in milk sold at different regions of Dehradun. 100 random raw milk samples were collected from dairy owners from 30 different regions of Dehradun. Out of 100 milk samples analyzed for adulteration, adulterants found were glucose $(80 \%)$, skimmed milk powder $(58 \%)$, salt $(51 \%)$ and urea $(35 \%)$ while found negative for formalin, salicylic acid, boric acid, starch, soap this milk may also cause serious human health related problems. A national survey in India has revealed that almost $70 \%$ of the milk sold and consumed in India is adulterated by contaminants such as detergent and skim milk powder, but impure water is the highest contaminant. According to National Survey on Milk Adulteration conducted by FSSAI (2011) water is the most common adulterant followed by detergent in milk. Again a survey was done by FSSAI (2012), 68\% milk samples were found to be adulterated in which $31 \%$ were from rural areas. Of these $16.70 \%$ were packet or branded milk and rest were loose milk samples from dairies. In the urban areas, $68.9 \%$ milk was found to be adulterated with water, detergent, urea and skim milk powder. In Uttarakhand, $88 \%$ milk was found to be adulterated. Despite the laws governing the quality and sell of milk existing in India for decades, the adulterants of milk has not been checked completely. Kumar et al. (2015) collected 50 milk samples from Godaulia and Pandeypur milk mandi of Varanasi (U.P.). The milk samples were tested for adulterants used and these were grouped in three classes i.e. Group I: Starch, Sucrose, Glucose and Skim Milk Powder, Group II: Acidity/Alkalinity, Neutralizers, Sodium Chloride and Urea; Group III: Formalin, Hydrogen Peroxide and Detergents. Under group first, all the samples tested were found negative for glucose, while $20 \%$ samples were positive for starch. In second group, $80 \%$ of the samples tested were found positive for Acidity/Alkalinity. In these samples the extent of adulteration with neutralizers, sodium chloride and urea were $28 \%, 80 \%$ and $60 \%$, respectively. In third group, $30 \%$ of milk samples were positive for formalin and $36 \%$ for hydrogen peroxide. Similarly, $44 \%$ of milk samples were positive for detergents.

\section{Materials and Methods \\ Collection of the milk samples}

The study was conducted during January to February, 2016 with two types of the milk samples (30 raw and 20 packaged). Total 50 milk samples were collected in 100 $\mathrm{ml}$ screw capped sterile bottles from 10 different cites (Dankeen Ganj, Panditan, Railway Bazar, Bus Station, Bharhuna, Vindhyachal, Peelikothi, Awas Vikas Colony, Wellesly Ganj and Mahuvaria) of the Mirzapur city in the morning and transported without any delay. All the possible precautions were taken to avoid external contamination at the time of collection of samples and during processing. After collection, the samples were brought to the laboratory for further analysis. The experimentation and testing work have done in the laboratory of Department of Animal Husbandry \& Dairying, Institute of Agricultural Sciences, Banaras Hindu University, Varanasi (U.P.).

\section{Analysis of milk samples}

The milk samples were tested as per methods given by FSSAI (2015) for detection of adulterants i.e. urea, salt, soap, skimmed milk powder, glucose, formalin, salicylic acid, boric acid, starch and ammonium sulphate. The results of adulteration tests were also confirmed with using the HiMedia Adulteration Testing Kit protocol (HIMEDIA laboratories, Mumbai, India). All tests were repeated thrice.

1. Test for detection of Urea: Urea is generally added in the preparation of synthetic milk to raise the SNF value. $5 \mathrm{ml}$ of milk is mixed well with $5 \mathrm{ml}$ paradimethyl amino benzaldehyde reagent. If the solution turns distinct yellow in colour, then the given sample of milk contains urea. Control, normal milk may show a faint yellow colour due to presence of natural urea. Take $5 \mathrm{ml}$ of milk in a test tube. Add $0.2 \mathrm{ml}$ of fresh urease $(20 \mathrm{mg}$ / $\mathrm{ml})$. Shake well at room temperature. Add 0.1 $\mathrm{ml}$ of bromothymol blue solution. Appearance of blue colour after $10-15$ min indicates the adulteration milk with urea. 
2. Test for detection of Salt: Take $5 \mathrm{ml}$ of Silver Nitrate reagent in a test tube. Add 2-3 drops of Potassium Dichromate Reagent. Add $1 \mathrm{ml}$ of milk in this test tube and mix thoroughly. If the content of the test tube turn yellow, then milk contains salt. If it turns to chocolate colour or reddish brown, the milk sample is free from salt.

3. Test for detection of soap: Measure out 10 $\mathrm{ml}$ milk into a test tube. Add $10 \mathrm{ml}$ of hot water into the test tube containing milk. Now add 1-2 drops of phenolphthalein indicator solution into the test tube. Gently mix the contents of the test tube. Development of pink colour on addition of phenolphthalein indicator confirms the presence of soap in milk.

4. Test for detection of Skim milk powder: If, the addition of nitric acid drop by drop in to the test milk sample results in the development of orange colour. It indicates the milk is adulterated with skim milk powder. Samples without skim milk powder shows yellow colour.

5. Test for detection of Glucose: Poor quality glucose is sometimes added to milk to increase the lactometer reading. Take $3 \mathrm{ml}$ of milk in a test tube. Add $3 \mathrm{ml}$ Bar ford's reagent and mix it thoroughly. Keep the test tube in a boiling water bath for $3 \mathrm{~min}$ and then cool it for $2 \mathrm{~min}$ by immersing it in tap water without disturbance. Add $1 \mathrm{ml}$ of phosphomolybdic acid and shake. If blue colour is visible, then glucose is present in the milk sample.

6. Test for detection of Formalin: Formalin $(40 \%)$ although poisonous, can preserve milk for a long time. Take $10 \mathrm{ml}$ of milk in a test tube. Add $5 \mathrm{ml}$ conc. sulphuric acid through the sides of the test tube without shaking. If a violet or blue ring appears at the intersection of the two layers, it shows the presence of formalin. One thing should be noted that violet coloration usually does not appear when relatively large quantities of formaldehyde are present.

7. Test for detection of Salicylic acid: Take 5 $\mathrm{ml}$ of milk in a test tube. Add 3-4 drops of concentrated sulphuric acid. Add $0.5 \%$ ferric chloride solution drop by drop and mix well. Development of buff colour indicates presence of benzoic acid and violet colour indicates presence of salicylic acid.

8. Test for detection of Boric acid test: Take $5 \mathrm{ml}$ milk in a test tube. Add $1 \mathrm{ml}$ of concentrated hydrochloric acid and mix well. Dip the tip of turmeric paper into the acidified milk and dry in a watch glass at $100^{\circ} \mathrm{C}$ or over a small flame. If the turmeric paper turns red, it indicates the presence of borax or boric acid. Add a drop of ammonia solution on the turmeric paper and if the red colour changes to green, it confirms the presence of boric acid. The following two adulteration tests are difficult to carry out by regular consumers as they require sophisticated equipments and so can be conducted only by qualified analysts. It is mentioned here in as additional information and for understanding.

9. Test for detection of Starch: Take $5 \mathrm{ml}$ of hot milk in a test tube. Add a few drops of tincture of Iodine or Iodine solution. Formation of blue colour indicates the presence of starch.

10. Test for detection of Ammonium sulphate: Take $5 \mathrm{ml}$ of hot milk in a test tube. Add a suitable acid, e.g. Citric Acid. The whey obtained is separated and filtered. Take the whey in another test tube and add $0.5 \mathrm{ml}$ of $5 \%$ Barium Chloride. Appearance of precipitate indicates the presence of Ammonium Sulphate. The presence of Ammonium sulphate in milk increases the lactometer reading.

\section{Results and Discussion}

Urea, salt and soap test of collected milk samples

Data of collected milk samples were analyzed for urea, salt and soap are presented in Table- 1 . This table revealed that $80 \%, 56 \%$ and $54 \%$ samples tested were found positive for urea, salt and soap, respectively. While, $20 \%, 44 \%$ and $36 \%$ number of samples were found negative in tests. It means, these chemicals are used as cheap preservatives which may increase the shelf-life of milk. Soap may be detected due to low maintenance of milk tanks while preparation or it can be used to mask fat value of milk. All these chemicals are very harmful if consumed in excess quantity.

Skimmed milk powder, glucose and formalin test of collected milk samples

As evident from Table-2, 42\% samples were found positive for skimmed milk powder test. This explains the adulterant is used to either increase the weight or relative 
mass of natural milk. Only $10 \%$ samples were positive for glucose. The purpose of using glucose may be to prolong the keeping quality of milk. Similarly, $36 \%$ of milk samples were found positive for formalin. It is generally used to enhance the keeping quality of milk as preservative.

Table-1: Adulteration of urea, salt and soap in milk samples $(n=50)$

\begin{tabular}{|c|c|c|c|c|c|c|c|c|}
\hline \multirow{2}{*}{$\begin{array}{l}\text { S. } \\
\text { No. }\end{array}$} & \multirow{2}{*}{ Cites / Areas } & \multirow{2}{*}{ Type of milk } & \multicolumn{2}{|c|}{ Urea } & \multicolumn{2}{|c|}{ Salt } & \multicolumn{2}{|c|}{ Soap } \\
\hline & & & $+\mathrm{ve}$ & - ve & + ve & - ve & $+v e$ & - ve \\
\hline \multirow{2}{*}{1} & \multirow{2}{*}{ Dankeen Ganj } & Raw Milk & 3 & 0 & 2 & 1 & 1 & 2 \\
\hline & & Packaged milk & 1 & 1 & 0 & 2 & 0 & 2 \\
\hline \multirow{2}{*}{2} & \multirow{2}{*}{ Panditan } & Raw Milk & 3 & 0 & 2 & 1 & 1 & 2 \\
\hline & & Packaged milk & 0 & 2 & 0 & 2 & 0 & 2 \\
\hline \multirow{2}{*}{3} & \multirow{2}{*}{ Railway Bazar } & Raw Milk & 3 & 0 & 3 & 0 & 3 & 0 \\
\hline & & Packaged milk & 0 & 2 & 0 & 2 & 0 & 2 \\
\hline \multirow{2}{*}{4} & \multirow{2}{*}{ Bus Station } & Raw Milk & 3 & 0 & 3 & 0 & 3 & 0 \\
\hline & & Packaged milk & 2 & 0 & 1 & 1 & 0 & 2 \\
\hline \multirow{2}{*}{5} & \multirow{2}{*}{ Bharhuna } & Raw Milk & 3 & 0 & 2 & 1 & 1 & 2 \\
\hline & & Packaged milk & 2 & 0 & 1 & 1 & 0 & 2 \\
\hline \multirow{2}{*}{6} & \multirow{2}{*}{ Vindhyachal } & Raw Milk & 3 & 0 & 3 & 0 & 2 & 1 \\
\hline & & Packaged milk & 2 & 0 & 0 & 2 & 1 & 1 \\
\hline \multirow{2}{*}{7} & \multirow{2}{*}{ Peelikothi } & Raw Milk & 3 & 0 & 3 & 0 & 2 & 1 \\
\hline & & Packaged milk & 2 & 0 & 1 & 1 & 0 & 2 \\
\hline \multirow{2}{*}{8} & \multirow{2}{*}{$\begin{array}{l}\text { Awas Vikas } \\
\text { Colony }\end{array}$} & Raw Milk & 3 & 0 & 2 & 1 & 3 & 0 \\
\hline & & Packaged milk & 1 & 1 & 1 & 1 & 2 & 0 \\
\hline \multirow{2}{*}{9} & \multirow{2}{*}{ Wellesly Ganj } & Raw Milk & 3 & 0 & 2 & 1 & 3 & 0 \\
\hline & & Packaged milk & 0 & 2 & 0 & 2 & 1 & 1 \\
\hline \multirow{2}{*}{10} & \multirow{2}{*}{ Mahuvaria } & Raw Milk & 3 & 0 & 2 & 1 & 3 & 0 \\
\hline & & Packaged milk & 0 & 2 & 0 & 2 & 1 & 1 \\
\hline \multicolumn{3}{|c|}{ No. of samples (+ve / -ve) } & 40 & 10 & 28 & 22 & 27 & 23 \\
\hline \multicolumn{3}{|c|}{$\%$ no. of samples (+ve / -ve) } & 80 & 20 & 56 & 44 & 54 & 36 \\
\hline
\end{tabular}

Salicylic acid, boric acid, starch and ammonium sulphate test of milk samples

The extent of adulteration of salicylic acid, boric acid, starch and ammonium sulphate is given in Table-3. It depicted that $56 \%$ and $32 \%$ milk samples were noticed positive for salicylic acid and boric acid. These both chemicals increase the acidity of milk. It is also evident from the same table that $38 \%$ samples were adulterated with starch. It means starch is usually used as thickening agent in milk with water. While, $12 \%$ of collected samples (raw and packaged) were recorded positive for ammonium sulphate. It may also be used as self-life enhancer agent of milk. 
Table-2: Adulteration of skimmed milk powder, glucose and formalin in milk samples $(\mathbf{n}=\mathbf{5 0})$

\begin{tabular}{|c|c|c|c|c|c|c|c|c|}
\hline \multirow{2}{*}{$\begin{array}{c}\text { S. } \\
\text { No. }\end{array}$} & \multirow{2}{*}{ Cite / Areas } & \multirow{2}{*}{ Type of milk } & \multicolumn{2}{|c|}{ Skimmed milk } & \multicolumn{2}{|c|}{ Glucose } & \multicolumn{2}{|c|}{ Formalin } \\
\hline & & & + ve & - ve & + ve & - ve & + ve & - ve \\
\hline \multirow{2}{*}{1} & \multirow{2}{*}{ Dankeen Ganj } & Raw Milk & 3 & 0 & 0 & 3 & 1 & 2 \\
\hline & & Packaged milk & 1 & 1 & 0 & 2 & 0 & 2 \\
\hline \multirow{2}{*}{2} & \multirow{2}{*}{ Panditan } & Raw Milk & 0 & 3 & 0 & 3 & 1 & 2 \\
\hline & & Packaged milk & 2 & 0 & 0 & 2 & 1 & 1 \\
\hline \multirow{2}{*}{3} & \multirow{2}{*}{ Railway Bazar } & Raw Milk & 0 & 3 & 0 & 3 & 1 & 2 \\
\hline & & Packaged milk & 1 & 1 & 0 & 2 & 0 & 2 \\
\hline \multirow{2}{*}{4} & \multirow{2}{*}{ Bus Station } & Raw Milk & 0 & 3 & 1 & 2 & 1 & 2 \\
\hline & & Packaged milk & 2 & 0 & 0 & 2 & 1 & 1 \\
\hline \multirow{2}{*}{5} & \multirow{2}{*}{ Bharhuna } & Raw Milk & 0 & 3 & 0 & 3 & 1 & 2 \\
\hline & & Packaged milk & 2 & 0 & 0 & 2 & 0 & 2 \\
\hline \multirow{2}{*}{6} & \multirow{2}{*}{ Vindhyachal } & Raw Milk & 1 & 2 & 1 & 2 & 2 & 1 \\
\hline & & Packaged milk & 0 & 2 & 0 & 2 & 1 & 1 \\
\hline \multirow{2}{*}{7} & \multirow{2}{*}{ Peelikothi } & Raw Milk & 1 & 2 & 1 & 2 & 2 & 1 \\
\hline & & Packaged milk & 1 & 1 & 0 & 2 & 0 & 2 \\
\hline \multirow{2}{*}{8} & \multirow{2}{*}{$\begin{array}{l}\text { Awas Vikas } \\
\text { Colony }\end{array}$} & Raw Milk & 2 & 1 & 0 & 3 & 1 & 2 \\
\hline & & Packaged milk & 1 & 1 & 0 & 2 & 1 & 1 \\
\hline \multirow{2}{*}{9} & \multirow{2}{*}{ Wellesly Ganj } & Raw Milk & 1 & 2 & 1 & 2 & 1 & 2 \\
\hline & & Packaged milk & 0 & 2 & 0 & 2 & 1 & 1 \\
\hline \multirow{2}{*}{10} & \multirow{2}{*}{ Mahuvaria } & Raw Milk & 2 & 1 & 1 & 2 & 1 & 2 \\
\hline & & Packaged milk & 1 & 1 & 0 & 2 & 1 & 1 \\
\hline \multicolumn{3}{|c|}{ No. of samples (+ve / -ve) } & 21 & 29 & 05 & 45 & 18 & 32 \\
\hline \multicolumn{3}{|c|}{ \% no. of samples (+ve / -ve) } & 42 & 58 & 10 & 90 & 36 & 64 \\
\hline
\end{tabular}


Table-3: Adulteration of salicylic acid, boric acid, starch and ammonium sulphate in milk samples $(\mathbf{n}=\mathbf{5 0})$

\begin{tabular}{|c|c|c|c|c|c|c|c|c|c|c|}
\hline \multirow{2}{*}{$\begin{array}{c}\text { S. } \\
\text { No. }\end{array}$} & \multirow{2}{*}{ Cites / Areas } & \multirow{2}{*}{ Type of milk } & \multicolumn{2}{|c|}{ Salicylic acid } & \multicolumn{2}{|c|}{ Boric acid } & \multicolumn{2}{|c|}{ Starch } & \multicolumn{2}{|c|}{$\begin{array}{c}\text { Ammonium } \\
\text { sulphate }\end{array}$} \\
\hline & & & $+\mathrm{ve}$ & - ve & + ve & - ve & $+\mathrm{ve}$ & -ve & + ve & -ve \\
\hline \multirow{2}{*}{1} & \multirow{2}{*}{ Dankeen Ganj } & Raw Milk & 3 & 0 & 1 & 2 & 2 & 1 & 0 & 3 \\
\hline & & Packaged milk & 1 & 1 & 0 & 2 & 0 & 2 & 0 & 2 \\
\hline \multirow{2}{*}{2} & \multirow{2}{*}{ Panditan } & Raw Milk & 1 & 2 & 2 & 1 & 1 & 2 & 1 & 2 \\
\hline & & Packaged milk & 0 & 2 & 0 & 2 & 0 & 2 & 0 & 2 \\
\hline \multirow{2}{*}{3} & \multirow{2}{*}{ Railway Bazar } & Raw Milk & 2 & 1 & 1 & 2 & 2 & 1 & 0 & 3 \\
\hline & & Packaged milk & 1 & 1 & 0 & 2 & 0 & 2 & 0 & 2 \\
\hline \multirow{2}{*}{4} & \multirow{2}{*}{ Bus Station } & Raw Milk & 3 & 0 & 1 & 2 & 0 & 3 & 0 & 3 \\
\hline & & Packaged milk & 2 & 0 & 1 & 1 & 0 & 2 & 0 & 2 \\
\hline \multirow{2}{*}{5} & \multirow{2}{*}{ Bharhuna } & Raw Milk & 0 & 3 & 1 & 2 & 1 & 2 & 1 & 2 \\
\hline & & Packaged milk & 2 & 0 & 0 & 2 & 0 & 2 & 0 & 2 \\
\hline \multirow{2}{*}{6} & \multirow{2}{*}{ Vindhyachal } & Raw Milk & 1 & 2 & 1 & 2 & 2 & 1 & 1 & 2 \\
\hline & & Packaged milk & 1 & 1 & 0 & 2 & 0 & 2 & 0 & 2 \\
\hline \multirow{2}{*}{7} & \multirow{2}{*}{ Peelikothi } & Raw Milk & 2 & 1 & 1 & 2 & 2 & 1 & 1 & 2 \\
\hline & & Packaged milk & 1 & 1 & 0 & 2 & 0 & 2 & 0 & 2 \\
\hline \multirow{2}{*}{8} & \multirow{2}{*}{$\begin{array}{l}\text { Awas Vikas } \\
\text { Colony }\end{array}$} & Raw Milk & 2 & 1 & 3 & 0 & 2 & 1 & 0 & 3 \\
\hline & & Packaged milk & 1 & 1 & 1 & 1 & 1 & 1 & 0 & 2 \\
\hline \multirow{2}{*}{9} & \multirow{2}{*}{ Wellesly Ganj } & Raw Milk & 1 & 2 & 1 & 2 & 2 & 1 & 1 & 2 \\
\hline & & Packaged milk & 0 & 2 & 0 & 2 & 0 & 2 & 0 & 2 \\
\hline \multirow{2}{*}{10} & \multirow{2}{*}{ Mahuvaria } & Raw Milk & 3 & 0 & 2 & 1 & 3 & 0 & 1 & 2 \\
\hline & & Packaged milk & 1 & 1 & 0 & 2 & 1 & 1 & 0 & 2 \\
\hline \multicolumn{3}{|c|}{ No. of samples (+ve / -ve) } & 28 & 22 & 16 & 34 & 19 & 31 & 06 & 44 \\
\hline \multicolumn{3}{|c|}{ \% no. of samples (+ve / -ve) } & 56 & 44 & 32 & 68 & 38 & 62 & 12 & 88 \\
\hline
\end{tabular}

\section{Conclusion}

It is noticeable from the present investigation that most of the milk samples collected from different cites of the Mirzapur city did not conform to the legal standards prescribed by PFA (1954) and Food Safety and Standards
Authority of India (FSSAI). Findings clearly indicate that most of the milk samples were adulterated. The extent of adulteration varied significantly with highest percentage for urea $(80 \%)$ and least for glucose $(10 \%)$. This portrays that most of the milk samples were 
prepared with added adulterants during their production and processing or added intentionally according to one's own choice to generate more money. In a country such as India where milk and milk products play an important role in different foodstuffs, this analysis carried out would bring more awareness to the general public about the malpractices in milk production.

\section{References}

1. Alauddin (2012). Food Adulteration and Society. Global Research Analysis, 1(7): 3-5.

2. FSSAI (2011). Executive Summary on National Survey on Milk Adulteration.

3. FSSAI (2012). Executive Summary on National Survey on Milk Adulteration.

4. FSSAI (2015). Lab Manual-I. Manual of methods for analysis of foods: Milk and milk products.

5. Grace, D., Baker, D. and Tom, R. (2009). Innovative and participatory risk-based approaches to assess milk safety in developing countries: A case study in North East India. In: International Association of Agricultural Economists (IAAE) Conference in Beijing, China, 17-22 August, 2009, pp. 1-10.

6. Kandpal, S.D., Srivastava, S.K. and Negi, K.S. (2012). Estimation of quality of raw milk (open and branded) by milk adulteration testing kit. Indian Journal of Community Health, 5(3): 22-26.

7. Kumar, A., Goyal, S.K., Pradhan, R.C. and Goyal, R.K. (2015). A study on status of milk adulterants using in Milk of District Varanasi. South Asian Journal of Food Technology and Environment, 1(2): 140-143.

8. Lingathurai, S., Vellathurai, P., Vendan, S.E. and Anand, A.A.P. (2009). A comparative study on the microbiological and chemical composition of cow milk from different locations in Madurai, Tamil Nadu. Indian Journal of Science and Technology, 2(2): 51-54.

9. Mahmood, A. and Usman S. (2010). A comparative study on the physicochemical parameters of milk samples collected from buffalo, cow, goat and sheep of Gujarat, Pakistan. Pakistan Journal of Nutrition, 9(12): 1192-1197.
10. NDDB

(2016). www.nddb.org/information/stats/milkpr odindia, cited on 23.04.2016.

11. NDRI (2002). Annual report of National Dairy Research Institute, Karnal (Haryana).

12. Nirwal, S., Pant, R. and Rai, N. (2013). Analysis of milk quality, adulteration and mastitis in milk samples collected from different regions of Dehradun. International Journal of Pharmtech Research, 5(2): 359-364.

13. Sarwar, M., Khan, M.A. and Mahr-UnNisa, Z.I. (2002). Dairy Industry in Pakistan: A scenario. International Journal of Agriulture Biology, 4: 420428.

14. Wadekar, S.B., Chavan, B.R. and Menkudale, G.C. (2011). Survey on adulteration of the milk received from Government milk scheme in Nanded town. Interlink Research Analysis, 1: 3235. 